\title{
Fiscal Illusions in Local Self-government Finance. Complementarity of Qualitative and Quantitative Methods*
}

\author{
Beata Guziejewska \\ University of Lodz, Lodz, Poland
}

\begin{abstract}
This paper presents the conclusions from the qualitative and quantitative parts of the project, the aim of which was to investigate the consequences of the current system of financing local self-government in Poland in the context of a broader phenomenon, the so-called "fiscal illusion". The first part of the research (qualitative) was based on in-depth interviews with 10 councilors of the Municipal Council of Lodz (Łódź); the second part was based on an improved questionnaire and closed-ended questions (quantitative). The questionnaire was sent by email to the councilors of seven largest cities, in terms of population, in Poland. The main results reveal little importance of local taxes and local fiscal autonomy in the eyes of the members of the council. The largest group of respondents (86\%) pointed to higher shares in PIT (Personal Income Tax) and CIT (Corporate Income Tax) and higher subsidy and grants from the central budget (68\%) as the most desirable method of raising revenues for the municipal budget. The $71 \%$ of the respondents were against increasing local taxation. This paper summarizes the results from the whole research project and refers to the hypotheses. The synthetic findings fully confirmed the main research hypothesis, which stated that the system of financing local government in Poland, which was based on revenues from transfers, led to the origin and perpetuation of fiscal illusion.
\end{abstract}

Keywords: fiscal illusions, fiscal relations, local taxes, grants

The aim of the research was to investigate the types, scope, and consequences of the current system of financing Polish local self-government entities in view of fiscal illusion. The present structure of local revenues in Poland is characterized by little financial importance of local taxes and fees and a high contribution of revenues from all kinds of transfers, such as general grants, specific grants, and common taxes like PIT (Personal Income Tax) and CIT (Corporate Income Tax). The main paradigm of and the condition for decentralization is that it mainly depends on local finance, local autonomy, and fiscal responsibility in levying local taxes and fees. If the scope of transfers is wide, the "bad", opportunistic local politicians are in a favorable and "safe" position. This is the main rationale for the study to have been undertaken. The overall research hypothesis assumes that the system of financing local government based on transfer revenues results in the origin and perpetuation of fiscal illusion.

In broad terms, an illusion is a false belief, a distorted, erroneous interpretation of things. In public finance, the problem concerns fiscal instruments and financial phenomena. The concept of "fiscal illusion" in the

\footnotetext{
${ }^{*}$ Research project is financed by Polish National Science Center, 2014/13/B/HS4/00162, "The role of the system of financing local government in the creation and perpetuation of fiscal illusion. Complementarity of qualitative and quantitative methods".

Corresponding author: Beata Guziejewska, associate professor, head of the Chair of Public Finance, University of Lodz, Lodz, Poland; research fields: public finance, fiscal relations, self-government finance.
} 
context of local finance was provided by the author in previous publications (Guziejewska, 2013, pp. 24-32; 2016, pp. 215-218). Fiscal illusion is a distorted, erroneous interpretation, a false belief about public finance and fiscal issues. The foundations for the problem of fiscal illusions in public finance and fiscal policy were laid by Italian economists, A. Puviani and M. Fasiani. In this approach, the role of the structure of political institutions is emphasized and the ruling class creates illusions, suggesting to the taxpayers that the level of taxation is lower than it really is, and that the taxpayers benefit from a higher value of public services (Buchanan, 1997, pp. 158-171). According to Dollery and Worthington (1996, p. 261), fiscal illusion means that: "the true costs and benefits of government may be consistently misconstrued by the citizenry of a given fiscal jurisdiction".

The problem is also analyzed in the context of the system of subsidies for local government and relations between the policy concerning the sources of revenue and expenditure and maximization of the politicians' chances of election (Mueller, 2003, p. 221). In terms of decentralization, the problem of fiscal illusion revolves around the consequences of complexity of intergovernmental fiscal relations [OECD (Organization for Economic Co-operation and Development), 2013]. The problems pointed out in the project are related to emerging second generation approaches to fiscal decentralization, which underline the importance of political processes and behavior of political agents (Duc Hong Vo, 2010, p. 673; Green, 2012, pp. 295-326; Brender \& Drazen, 2004, pp. 1271-1295; Mourao, 2010, pp. 232-236). Boadway and Shah (2009, p. 281) emphasized the fact that: “... accountability to local residents has been the factor most critical to the success of local governance in industrial countries".

\section{The Stages of the Study}

The study was divided into three stages and involved two methods that differed in their approach. Due to the difficulty in identifying and measuring illusions in social life, the project was designed to combine the qualitative and quantitative methods of research. The first stage (May/June 2015) involved conducting 10 targeted in-depth interviews with the members of the Municipal Council of Lodz (Łódź). The division of the research process into stages enabled to check whether the questionnaire had been designed correctly (pre-test function). Apart from the in-depth interviews, a preliminary questionnaire survey was conducted in the first stage of the research. The two elements may be treated as a projective test, which is an experimental tool. The aim of a projective test is to reveal what is hidden or "ambiguous". The technique uses the so-called projection defense mechanism, a projection mechanism in uncomfortable situations. In the second stage of the research (December 2015/January 2016), an improved questionnaire and closed-ended questions based on the five-level Likert scale were used. The questionnaire, which contained 12 questions, was made short on purpose. First nine questions concerned various aspects of fiscal illusion. The last three questions dealt with political attitudes, the type of education, and seniority in the city council. The questionnaire was sent by email to the councilors of seven largest, in terms of population, cities in Poland (with the exception of the capital city of Warsaw). Although the number of councilors in the 2014-2018 term of office exceeded 250, the response rate was low and stood at about $23 \%{ }^{1}$. It should be underlined that fiscal illusion is a phenomenon which is very difficult to measure and, in general, very difficult to investigate. In the third stage of the research, the outcomes of the

\footnotetext{
1 The determinants and the reasons of this low response rate, as well as the aspect of intensity of fiscal illusion in local self-government in Poland were presented and discussed at the ICESM 2016 Conference in Rome and will be published in International Journal of Trade, Economics and Finance.
} 
surveys (56 questionnaires) were analyzed with the use of basic statistical analysis methods and confronted with the main conclusions learned from the in-depth interviews.

\section{The Conclusions From Qualitative Part of the Research}

The in-depth interviews with 10 city councilors were conducted between May 14 and June 16, 2015. The general conclusions from the qualitative research may be laid out in the following points:

(1) The assumptions for the research had included a high level of general knowledge of the finance system for local self-government. The respondents declared that indeed they were interested in finances. Their interest, however, concerned matters that proved unimportant for the whole of the system, despite the fact that they were quite important from the point of view of an individual citizen. The local government economy involves various tasks that are addressed by the councilors. These include education, safety, transport, tenant housing, legal counseling and advice, culture and promotion, as well as finance. Such a vast scope of issues makes it impossible for the councilors to gain specialist knowledge in a given field. They deal with many problems in an ad hoc manner, which also regards finances. Although the overall knowledge of the scope of financing local government tasks is poor, it is also diversified.

(2) The responses to specific questions reveal a high degree of fiscal illusion. The councilors, for instance, failed to mention local taxes and fees as the main source of revenue for the city budget. They listed shares in PIT and CIT and the general subsidy as the main source of revenue and they postulated an increase in the revenues from these sources. Generally, they voiced opinions against a rise in local taxes and fees in their responses not only to the questions directly referring to raising taxes but also to those that concerned changes to the overall structure of the sources of revenue. Their attitude against the changes was justified by previous experiences where the central government had not observed the principle of adequacy. Also, many respondents considered the present system of revenue as good. They thought that it did not require any basic changes.

(3) When asked about the possibility of raising own revenues, some councilors were against imposing more tax burden on citizens. Instead, they pointed out a necessity to more efficiently execute the due revenues. It was difficult to collect a response that would have advocated systemic solutions in order to increase the level of revenue at a local government's disposal. The most common postulate in the responses regarded an increase in the transfer revenues (shares in PIT, the subsidy, and grants) and a rise in the education part of the general subsidy. What was also mentioned was a necessity to develop local economy, which would lead to higher revenues. The author is of the opinion that such responses reveal the councilors' reluctance to make difficult decisions to increase local taxes. Generally, the responses voiced the councilors' aversion to increasing local taxes while they ignored the fact that the revenues from the subsidy come from the taxes collected at the central level.

(4) None of the interviews contained a proposal to increase fiscal independence of local governments, which pointed to a wide scope of fiscal illusion. What prevailed was the attitude that stressed the role of politicians at the central level, not the local ones, in the making of fiscal decisions that concerned the revenue side of the budget. At the same time, there were no attitudes that would be extremely demanding or dogmatic, not accepting other points of view. Some of the councilors were proponents of the tax on the value of real estate, pointing to the paradoxes in the present system of real estate management. This was surprising as the tax is commonly associated in Poland with a high tax burden. 
(5) Although the views on this issue varied, the level of debt was indicated as a basic problem in the system of local government finance. Some respondents pointed to failed investments; some others, on the other hand, stressed that the debt came from investment effort, which, after all, promoted development. The councilors also underlined the unique opportunity to use EU (European Union) funds and a long-term necessity to raise the level of the quality of life for residents. The opposition councilors, however, expressed very critical views on excessive debt.

(6) The difficulties in obtaining unequivocal answers referred to the methods of reducing budget deficit by increasing revenue and decreasing expenditure. The respondents who tended to raise revenues in order to reduce budget deficit were not able to indicate which revenues should be raised, and they often avoided response.

(7) One of the interviews contained interesting suggestions on the necessity of a strategy for the management of municipal property or on the proposals to grant shares in VAT (Value Added Tax) to local self-governments. The councilors with a longer experience in local government or those who occupied important posts (for example the President of the City Council or the Chairman of the Finance Committee) showed a high level of general knowledge and presented interesting arguments supporting their views. However, the views of more general, systemic character that would address the essence of self-government and its fiscal autonomy, particularly with regard to the revenue side of the city budget, appeared very rarely.

As was mentioned earlier, what was noticeable in the interviews was that the level of knowledge of finance depended on the period of time spent in the local government, which may lead to the origin of fiscal illusions. It was very difficult in the interviews to break through the barrier created by the respondents who avoided direct answers to the questions or started a completely new topic. This attitude could result from opportunism or from fear of how the individual responses would be used. During the in-depth interviews, no specific vocabulary, extraordinary attitudes or behavior were observed. However, political issues and arguments were ascribed extraordinary importance. The issues and comments of political character raised by the councilors have been omitted in the discussion presented above. The politicization of local government economy at the time the questionnaires were sent to the councilors was particularly important as the study coincided with the period after the parliamentary elections in Poland.

\section{The Results of the Quantitative Part of the Research}

The outcomes of the survey were analyzed quantitatively using the methods of descriptive statistics, contingency tables, and selected statistical tests. Due to a small sample of respondents, the selected responses were aggregated for the purposes of statistical testing (e.g. "Yes" and "Rather Yes", "No" and "Rather No").

The widest scope of illusion occurs in the context of common taxes and transfer revenues (subsidy from the central budget) as well as in the context of how high the local taxes and fees should be. The largest group of respondents, 86\%, pointed to higher shares in PIT and CIT and higher subsidy and grants from the central budget $(68 \%)$ as the most desirable method of raising revenues for the municipal budget. The $71 \%$ of the respondents were against increasing local taxation.

Most respondents (62\%) answered both "Yes" and "Rather Yes" to the question about raising funds for the city budget by increasing shares in common taxes, and "No" and "Rather No" to the question whether local taxes and fees should be raised. In the discussed group of respondents, as many as $48 \%$ also indicated that local government should have more power in shaping local taxation. Not only does this prove a high level of illusions but also that these illusions are perpetuated. Another striking incongruity could be observed in the case 
of the question whether financing for local governments in the form of subsidies and grants from the central budget should be raised at the expense of local governments' financial independence. The 49 out of 56 councilors replied "No" and "Rather No".

A lower level of fiscal illusion was noted in the area of expenditure and the issues concerning budget deficit. As many as 52 out of 56 respondents were in favor of a reduction in budgetary expenditure in a situation of very high deficit. The 30 councilors were against financial assistance from the central budget in the case of cities at risk of bankruptcy.

In the context of the above results concerning both the revenue and the expenditure sides of the budget, it appears to be quite interesting that a vast majority of councilors declared centrist views ( 22 respondents) and right-wing views (21 respondents). Only six respondents declared left-wing views, three persons declared decidedly left-wing views and four persons professed definitely right-wing views. As was revealed in the analyses of the contingency tables, right-wing views do not have any effect on the incidence of fiscal illusion (a similar number of councilors answered "Yes" and "No" to selected questions).

The contingency tables, Fisher's exact test, and Yates' chi-square test were used in an attempt to investigate the existence of a correlation among the councilors' political views, their education, the length of term in the city council, and the origin of fiscal illusion. The test did not prove that there was a statistically significant correlation $\left(p>0.05\right.$, there are no reasons to reject $\left.H_{0}\right)$. It can be concluded that political views, education or the length of term do not have effect in the case of the questions that directly relate to the intensity of fiscal illusion. Statistical tests do not allow, however, for drawing unequivocal conclusions as they do not confirm the existence of a statistical correlation. This may be due either to the lack of the correlation itself or to the research sample that was too small. The impact of the three elements listed above on a better knowledge about the city finance presented by the councilors and a smaller scope of fiscal illusion was suggested in the in-depth interviews. This, however, was not confirmed by the statistical analyses.

\section{Summary and Conclusions}

The study conducted on the direct interviews does not satisfy the condition of representativeness. In principle, the study was supposed to act as a projection test that is an experimental tool. The in-depth interview did not yield the expected and assumed results in the part labeled as projection test, which is based on what is hidden or obscure. The author sees the main reason for a relatively low level of knowledge among the councilors in the overall system of financing local government, the structure and economic substance of individual sources of revenue. The respondents claimed that they were interested in financial matters only in the context of specific problems concerning the city and its inhabitants, which meant that the problems were insignificant or relatively small from the point of view of the whole of the financing system. Given the low level of knowledge, it was rather difficult to put forward questions that would analyze the problem in a deeper manner. In many interviews, the councilors pointed out that the tasks were delegated to local governments without adequate funding. However, these observations were not accompanied by either an insight into or a reflection on how local public tasks were financed and whether it was possible to change the system. A higher level of the councilors' knowledge of both the system of financing local government and the structure and principles behind individual local taxes was assumed for the purposes of the study. In this aspect, the results at this stage of the research did not meet the expectations. They were, however, extremely useful in rephrasing the existing questions in the original survey and formulating the new ones. 
The interviews and the preliminary test responses to the questionnaire revealed that the replies were often selected intuitively, somewhat mechanically. The responses were not based on a thorough knowledge of the system of financing local government. The respondents who had problems with the in-depth questions in the interview filled out the questionnaire in a rather haphazard manner. The author considers this fact to be significant for the final interpretation of the whole study. It also strongly suggests that combining the qualitative and quantitative methods is advisable, or even necessary.

The factual and synthetic findings from the research fully confirmed the main research hypothesis, which stated that the system of financing local government in Poland, which was based on revenues from transfers, led to the origin and perpetuation of fiscal illusion. The foregoing was definitely confirmed by both the qualitative and quantitative parts of the study in the area of the scope and types of illusion. The differences concerned the specific conditions for the origin of illusions, which were discussed above.

The specific hypotheses in the project were formulated as follows:

$\mathrm{H}_{1}$. The structure of local government revenue which is dominated by transfer revenues contributes to the misunderstanding of budgetary constraints and rules.

$\mathrm{H}_{2}$. A large share of transfer revenues in the financing of local government affects the growth rate of total expenditure and the so-called flypaper effect.

$\mathrm{H}_{3}$. Although they are against raising local taxes, councilors tend to demand an increase in the transfer revenues for the municipal budget, which reinforces demanding attitudes.

$\mathrm{H}_{4}$. The views of councilors on budgetary constraints and the tendency to increase revenues through local taxes are determined politically.

$\mathrm{H}_{5}$. A significant financial imbalance of the municipal budget does not curb the opportunistic attitudes of councilors.

$\mathrm{H}_{6}$. In the system of representative democracy, politicians acting as political entrepreneurs, who maximize their chances for re-election, are the main obstacles in the rational management of public finance.

The outcomes of the research project positively verified specific hypotheses $\mathrm{H}_{1}, \mathrm{H}_{3}$, and $\mathrm{H}_{6}$, whereas hypotheses $\mathrm{H}_{2}, \mathrm{H}_{4}$, and $\mathrm{H}_{5}$ were verified negatively. In general, the results from both parts of the research suggest that the councilors do not regard local taxes and fees as the main instrument of local fiscal policy. They expect the state authority to solve some problems, take rather unpopular decisions, and provide money. Thus, the results of the study confirm the concept of "political entrepreneurs", which is known from the doctrine of New Political Economy. The system which is characterized by a large amount of transfer revenue from the central budget is more convenient for opportunistic local politicians. In such a system, the positive effects of the accountability of local politicians to the residents disappear. As the theory says, close relations among those who pay charges and use public goods are necessary. In the light of the theory of fiscal federalism, a large portion of local government expenditure should be covered by local taxes which should, in turn, be characterized by territorial explicitness, a constant spatial relation of the tax base and the universality of tax burdens. Local government bodies and councilors should be held responsible for more financial decisions to the voters and their preferences. This sustains local democracy and allows for more rational management of public goods and finance.

Given the limited nature of the study, further analyses in specific areas will be required. It would be extremely interesting to address the following questions:

(1) To what extent is the origin of fiscal illusion conditioned by factors and circumstances of strictly political character, at the local and central tiers separately? 
(2) To what extent does fiscal illusion result from the lack of knowledge of economics and finance, or from opportunistic attitudes associated with the role of local politicians?

(3) Does the formation of fiscal illusion depend on councilors' political views, education, and the length of term in the city council?

Extending the scale of research would also allow for the use of more advanced statistical tools, which would yield far more conclusive results.

\section{References}

Boadway, R., \& Shah, A. (2009). Fiscal federalism: Principles and practice of multiorder governance. New York: Cambridge University Press.

Brender, A., \& Drazen, A. (2004). Political budget cycles in new versus established democracies. NBER Working Paper Series No. 10539. Retrieved from http://www.nber.org/papers/w10539.pdf

Buchanan, J. M. (1997). Public finance in democratic process: Fiscal institutions and individual choice (Polish edition). Warsaw: PWN.

Dollery, B., \& Worthington, A. (1996). The empirical analysis of fiscal illusion. Journal of Economics Surveys, 10(3), $261-297$. Blackwell Publishing.

Duc Hong Vo. (2010). The economics of fiscal decentralization. Journal of Economic Surveys, 24(4), 657-679. Blackwell Publishing Ltd.

Green, J. E. (2012). Public finance: An international perspective. Singapore: World Scientific Printers.

Guziejewska, B. (2013). Intergovernmental fiscal relations: Theoretical aspects and Poland's experience. Financial Internet Quarterly "e-Finanse", 9(3), 24-32. Retrieved from http://www.e-finanse.com

Guziejewska, B. (2016). Theoretical dimensions of fiscal illusions in local government finance. Journal of Economics, Business and Management, 4(3), 215-219.

Mourao, P. (2010). Fiscal illusion causes fiscal delusion—Please be careful! In Global Security, Safety, and Sustainability, 6th International Conference ICGS3 2010 Proceedings. Berlin: Springer-Verlag Berlin Heidelberg.

Mueller, D. C. (2003). Public choice III. Cambridge: Cambridge University Press.

OECD (Organization for Economic Co-operation and Development). (2013). Fiscal federalism 2014: Making decentralization work. Paris: OECD Publishing. 